\title{
Pelatihan Pembuatan Pupuk Organik dan Pemasaran bagi Warga di Kecamatan Pitiriawa Kabupaten Sidrap
}

\author{
Faris Jumawan*, Wawan Darmawan, Andi Febriana Tamrin \\ Universitas Fajar \\ faris@unifa.ac.id
}

\begin{abstract}
Abstrak
Program kegiatan KKN PPM ini bertujuan untuk meningkatkan kepedulian dan empati mahasiswa terhadap permasalahan yang dihadapi masyarakat desa KKN, sehingga terjadi perubahan perilaku mahasiswa, dan kelompok sasaran. Selain itu juga untuk memberdayakan masyarakat dalam pembuatan pupuk berbasis lokal di Kecamatan Pituriawa Kabupaten Sidrap. Peningkatan produksi dalam hal ini meliputi produksi pemakaian pupuk berbasis lokal. Selain itu, optimalisasi dan diversifikasi produk pupuk alami menjadi nilai tambah dalam meningkatkan penghasilan masyarakat. Dalam kegiatan ini pula akan di adakan pembelajaran bahasa Inggris untuk sekolah, pemuda karang taruna dan masyarakat/warga sekitar diharapkan mampu menerapkan teori-teori dasar bahasa inggris. Optimalisasi pelatihan bahasa inggris menjadi pendukung dalam pelabelan dan pemasaran produk pupuk berbasis lokal. Strategi yang digunakan adalah pemberdayaan kelompok sasaran dengan pendekatan PRA (partisipatory rural appraisal), dengan metode pendidikan, pelatihan, demplot, pendampingan. Rencana kegiatan meliputi: demplot, pelatihan dan pendampingan yang terlebih dahulu dilakukan sosialisasi melalui penyuluhan. Materi pelatihan meliputi: (1) penyuluhan pupuk; (2) pembuatan pupuk kompos; (3) pembuatan pupuk cair; (4) pelatihan bahasa inggris; (5) pelatihan pelabelan; (6) manajemen pemasaran produk; dan (7) penguatan jaringan pemasaran. Hasil yang dicapai adalah kemandirian masyarakat dalam membuat pupuk berbasis lokal sendiri sehingga mampu menekan biaya dari pembelian pupuk.
\end{abstract}

Kata Kunci: pupuk organik, pemasaran produk, pelabelan

\section{Training on Making Organic Fertilizer and Marketing for Residents in Pitiriawa District, Sidrap Regency}

\begin{abstract}
This KKN PPM activity program aims to increase student awareness and empathy towards the problems faced by the KKN village community, so that there is a change in the behavior of students and target groups. In addition, to empower the community in making local-based fertilizers in Pituriawa District, Sidrap Regency. Increased production in this case includes the production of using locally based fertilizers. In addition, optimization and diversification of natural fertilizer products is an added value in increasing people's income. In this activity, English learning will also be held for schools, youth organizations and local communities / residents are expected to be able to apply basic theories of English. The automation of English training is supporting the labeling and marketing of locally based fertilizer products. The strategy used is the empowerment of the target group with the PRA (Participatory Rural Appraisal) approach, with the methods of education, training, demonstration plots, and mentoring. The activity plan includes: demonstration plots, training and mentoring which is first carried out through outreach. The training materials include: (1) Fertilizer Extension, (2) Making Compost, (3) Making Liquid Fertilizer, (4) English Language Training, (5) Labeling training (6) Product Marketing Management, (7) strengthening marketing networks. The results achieved are community independence in making local-based fertilizers themselves so that they are able to reduce the cost of purchasing fertilizers.
\end{abstract}

Keywords: organic fertilizer, product marketing, labeling

\section{PENDAHULUAN}

Kabupaten Sidenreng Rappang merupakan salah satu kabupaten di Provinsi Sulawesi Selatan dengan luas wilayahnya mencapai 2,506 km2 Secara administratif, Desa Bulucenrana berada di Kecamatan Pituriawa Kabupaten Sidrap yang memiliki potensi pertanian dan perkebunan yang cukup besar. Mata pencaharian penduduk setempat salah 
satunya yaitu sektor pertanian dan perkebunan. Aktivitas pertanian dan perkebunan telah memberikan kontribusi cukup signifikan terhadap perekonomian masyarakat sekitar Desa Bulucenrana. Sektor pertanian era pemerintahan pada saat ini semakin di unggulkan untuk menjadi salah satu sektor dalam mendukung program kemandirian dan ketahanan pangan. Sebagai upaya merealisasikan program tersebut maka perlu dilakukan peningkatan pemahaman kepada masyarakat sehingga menjadi mandiri dalam sektor pertanian dan perkebunan salah satunya yaitu pembuatan pupuk. Sisa hasil pertanian dari para warga dapat digunakan sebagai bahan untuk pembuatan kompos. Pengomposan limbah-limbah pertanian secara alami dapat membutuhkan waktu kurang lebih 3-4 bulan(Wijayanto et al., 2019).

Mengingat pupuk untuk memenuhi kebutuhan pertanian masih di beli dari pabrikan yang diproduksi dari luar yang harganya cukup mahal, maka dari itu perlu dilakukan pemberdayaan pada petani sehingga mampu membuat atau memproduksi pupuk sendiri. Dengan adanya kemandirian dalam pembuatan pupuk maka akan mengurangi biaya pada proses pertanian dan perkebunan. Mengingat banyaknya sampah yang ada di desa, memungkinkan pembuatan pupuk dapat dilakukan. Untuk mewujudkan hal ini dibutuhkan pandangan baru yaitu segala sisa material dari proses, sampah memiliki keterpakaian dalam proses lainnya (Irianto and Amrul, 2017).

Pada program KKN-PPM ini, Desa Bulucenrana menjadi mitra yang pada umumnya penghasilan masyarakat dari hasil pertanian dan perkebunan. Berdasarkan pengamatan di Desa Bulucenrana, pengetahuan masyarakat dalam hal pembuatan pupuk masih kurang, oleh karenanya tim memutuskan bahwa dibutuhkan suatu kegiatan berupa sosialisasi dan pelatihan dalam pembuatan pupuk sehingga tercipta petani yang mandiri dan produktif. Petani ini diharapkan mampu membuat produk pupuk berbasis lokal kemudian dikemas dan dapat dijual di pasaran.

Untuk hal pemasaran, peserta dilatih dalam membuat pelabelan dan tentunya dalam pemasaran secara modern dalam bentuk media seperti internet. Strategi pemasaran merupakan suatu wujud rencana yang terurai pada bidang pemasaran. Untuk mendapatkan hasil yang diinginkan, dibutuhkan suatu strategi pemasaran yang memiliki ruang lingkup yang luas pada bidangnya (Praniti, Parining and Putra, 2016). Selain itu hal ini dapat dikatakan sebuah strategi bagi petani untuk menghadapi persaingan.

Dalam kegiatan ini pula akan di adakan pembelajaran bahasa Inggris untuk sekolah, pemuda karang taruna dan warga sekitar. Proses pembelajaran yang akan dilakukan oleh tim yaitu dengan menggunakan metode pembelajaran berbasis lingkungan. Metode ini merupakan salah satu metode yang penggunaannya masih sangat kurang di Indonesia. Hal ini dikarenakan sistem pembelajaran yang masih sangat sering digunakan adalah sistem tradisional yaitu belajar hanya pada kelas saja. Mengapa pembelajaran Bahasa Inggris berbasis lingkungan itu penting? Hal ini dikarenakan metode ini memberi dua manfaat sekaligus, yaitu belajar bahasa asing dan anak-anak diajar untuk mencintai lingkungan mereka (Tamrin, n.d.).

Memberikan ruang gerak baru bagi anak-anak untuk belajar bahasa asing, dalam hal ini bahasa Inggris pendidik haruslah pandai dalam meningkatkan minat mereka. Seperti yang telah dipaparkan sebelumnya, metode belajar bahasa Inggris berbasis lingkungan dapat dimulai dengan mengenalkan kepada anak-anak buku cerita berbahasa Inggris yang bertema alam. Ada beberapa buku yang memiliki tema alam yang mencerminkan kegiatan pengolahan sampah menjadi benda berguna seperti pupuk ataupun makanan ternak (Tamrin, n.d.). Mengenalkan buku cerita 
Vol. 2, No. 1, March, 2021, pp. 50-56

e-ISSN: 2722-2004

Training on

Making

Organic

Fertilizer and

Marketing for

Residents

in Pitiriawa

District,

Sidrap

Regency

F. Jumawan,

W. Darmawan,

A. F. Tamrin

berbahasa Inggris juga akan membuat mereka lebih mampu berimajinasi lebih baik. Mengajarkan nilai-nilai budaya untuk menjaga kebersihan akan membuat mereka terbiasa sedini mungkin. Dengan demikian rasa sadar akan pentingnya menjaga lingkungan akan terbentuk sedini mungkin (Tamrin and Magfirah, 2019). Karena itu metode ini sangatlah berguna dalam mengajarkan mereka untuk menjaga alam sekitarnya.

Peningkatan softskill juga sangat penting dalam era persaingan global terutama bahasa inggris dan keterampilan seperti membuat pupuk, peningkatan softskill juga mampu membuka lapangan usaha ataupun mampu bekerja dalam suatu perusahaan yang sifatnya internasional. Remaja yang memiliki kemampuan bahasa serta memiliki keahlian khusus seperti membuat pupuk akan memudahkan dalam membuat produk yang dikemas dengan menggunakan bahasa inggris dan dipromosikan dengan menggunakan bahasa inggris sehingga mampu meningkatkan taraf hidup dalam bermasyarakat serta ikut dalam membantu pemerintah dalam mengentaskan kemiskinan dan pengangguran.

\section{METODE PELAKSANAAN}

Kegiatan KKN PPM ini dilaksanakan melalui serangkaian tahapan, yaitu menentukan kelompok sasaran, perencanaan, pelaksanaan kegiatan KKN, dan evaluasi hasil. Kelompok sasaran utama kegiatan program KKN warga di Desa Bulucenrana.

Observasi sudah dilakukan dan rencana program sudah disusun berdasarkan tujuan program (potensi yang ada dan kendala yang dihadapi) dan pertimbangan dari masyarakat petani di Desa Bulucenrana untuk meningkatkan kelestarian lingkungan dan peningkatan kesejahteraan masyarakat. Pelaksanaan program akan dilakukan secara partisipatif melibatkan kelompok sasaran dan pada setiap aktivitasnya dilakukan bimbingan oleh mahasiswa. Kegiatan KKN PPM ini dilaksanakan oleh tim pengabdi, dalam hal ini mahasiswa beserta kelompok yang menjadi tanggung jawabnya. Hal ini bertujuan agar setelah kegiatan KKN PPM ini selesai kelompok sasaran ini akan mampu dan mau menularkan pengetahuan dan ketrampilan baru yang diperoleh dari kegiatan ini kepada masyarakat lainnya di tingkat Kelurahan maupun tingkat kecamatan.

Evaluasi hasil pelaksanaan kegiatan akan dilakukan baik selama berlangsungnya kegiatan maupun setelah selesai kegiatan. Secara periodik evaluasi dilakukan oleh Tim Pengusul setiap seminggu sekali dan oleh DPL setiap dua minggu sekali. Evaluasi ini dilakukan untuk menilai pelaksanaan program yang sudah terselesaikan secara bertahap dari minggu pertama ke minggu berikutnya. Selain itu evaluasi juga dilakukan oleh tim yang terdiri atas tim pelaksana dan DPL pada akhir periode KKN. Selain itu evaluasi juga akan dilakukan oleh pengurus kelompok petani/petani sendiri sehingga lebih obyektif. Hasil dari evaluasi akan digunakan sebagai dasar penyusunan program lanjutan.

Materi proses adalah materi yang dibekalkan kepada mahasiswa sebelum melaksanakan KKN PPM agar mahasiswa siap melakukan KKN PPM (falsafah KKN PPM), berisi penyusunan program KKN PPM secara parsitipatif (PRA), pelaporan, penilaian, dan tata tertib. Pembekalan materi proses akan diberikan oleh LPPM UNIFA, Dinas terkait, dan praktisi. Materi isi, adalah materi teknis yang 
diberikan kepada mahasiswa untuk diaplikasikan di lapangan sesuai dengan tema/judul KKN PPM. Seluruh mahasiswa mendapatkan pembekalan materi isi yang sama, namun tanggung jawab tiap materi selama menjalankan KKN PPM dikelompokkan sesuai dengan disiplin ilmu. Pembekalan materi isi akan diberikan oleh staf pengajar fakultas di lingkungan UNIFA yang sesuai bidang ilmunya, serta praktisi yang berpengalaman. Pembekalan tidak hanya berupa pemberian materi di dalam kelas, tetapi juga praktik di laboratorium di fakultas terkait di lingkungan UNIFA. Selain itu juga dilakukan praktik aplikasi di lapangan, sehingga mahasiswa mengalami lebih dahulu sebelum melakukan penyuluhan dan pengabdian kepada petani sasaran.

\section{HASIL DAN PEMBAHASAN}

Pelaksanaan kegiatan KKN PPM menggunakan pendekatan PRA (partisipatory rural appraisal). Dengan menerapkan pendekatan tersebut maka model pemberdayaan kelompok juga diterapkan. Langkah-langkah dalam bentuk program kegiatan yang akan dilaksanakan untuk mencapai hasil yang diharapkan sesuai dengan tema/judul KKN PPM ini dirinci dalam beberapa tahapan sebagai berikut:

1. Pembuatan Pupuk

Pembuatan pupuk terdiri dari dua program yakni melaksanakan penyuluhan tentang pembuatan pupuk dengan durasi waktu 5 jam dan penyuluhan pemanfaatan bahan lokal untuk dijadikan pupuk dengan durasi waktu 10 jam.

2. Pembuatan Kompos

Pada tahapan pembuatan kompos dibagi menjadi 6 program kegiatan yakni, penyuluhan tentang bahan pembuat pupuk kompos, syarat-syarat bahan untuk pupuk kompos, dan percontohan pupuk kompos yang masing-masing dilaksanakan selama 5 jam. Untuk program pengabdian pembuatan pupuk kompos dalam skala home industry, pembinaan pembuatan pupuk kompos pada tingkat kelompok, dan produksi pupuk kompos tiap kelompok masing-masing dilaksanakan selama 10 jam kerja.

3. Pembuatan Pupuk Cair

Pada tahapan pembuatan pupuk cair juga dibagi menjadi 6 program kegiatan yakni, penyuluhan tentang bahan pembuat pupuk kompos, penyuluhan syaratsyarat bahan untuk pupuk kompos, penyuluhan dan percontohan pupuk kompos, pengabdian pembuatan pupuk kompos dalam skala home industry, pembinaan pembuatan pupuk kompos pada tingkat kelompok, dan produksi pupuk kompos tiap kelompok yang masing-masing dilaksanakan selama 10 jam kerja.

4. Pelatihan Bahasa Inggris

Pada tahapan pelatihan bahasa Inggris terdiri dari 4 program yakni, penyuluhan pentingnya bisa berbahasa Inggris dengan durasi waktu 5 jam, pelatihan bahasa Inggris untuk anak sekolah, pelatihan bahasa inggris untuk pemuda karang taruna, dan. pelatihan bahasa Inggris untuk warga yang masing-masing dilaksanakan selama 10 jam kerja.

5. Pelatihan Pelabelan 
Vol. 2, No. 1, March, 2021, pp. 50-56

e-ISSN: 2722-2004

Training on

Making

Organic

Fertilizer and

Marketing for

Residents

in Pitiriawa

District,

Sidrap

Regency

F. Jumawan,

W. Darmawan,

A. F. Tamrin

Pada tahapan pelatihan pelabelan terdiri dari 3 program yakni, labelisasi produk dan pengembangan labelisasi menggunakan bahasa Inggris yang masing-masing dilaksanakan selama 5 jam, dilanjutkan dengan pendampingan selama $10 \mathrm{jam}$.

6. Manajemen Pemasaran Produk

Pada tahapan manajemen pemasaran produk terdiri dari 4 program yakni, analisis usaha pengembangan produk, pemasaran produk, pembiayaan usaha, pengembangan jejaring pasar produk yang masing-masing dilaksanakan selama 5 jam.

7. Penguatan kelompok

Pada tahapan penguatan kelompok terdiri dari 3 program yakni, penguatan manajemen kelompok dengan durasi waktu 5 jam, Dinamika kelembagaan dengan durasi waktu 10 jam dan Administrasi kelembagaan selama 5 jam kerja.

Kegiatan ini dilaksanakan selama 2 bulan dan melibatkan 30 mahasiswa yang dibagi kelompok untuk menjalankan beberapa program kegiatan.

Untuk menjamin kegiatan KKN PPM dapat mencapai tujuan yang sudah direncanakan, maka dalam proses pelaksanaannya akan dilakukan monitoring secara periodik setiap minggu. Dalam hal pengenalan lingkungan, terutama tanah, hal tersebut yang pertama kali ditanyakan kepada para petani. Untungnya, pemahaman mereka cukup baik dan mereka mampu memahami karakteristik tanaman padi serta menyatakan bahwa jenis tersebut tergolong tanaman yang ditanam semusim. Tanaman jenis ini ditanam pada agro ekosistem sawah yang tingkat kestabilannya dianggap kurang baik. Hal tersebut disebabkan karena mudahnya muncul masalah-masalah seperti hama, kesuburan tanah dan produksi. Alasan tersebut sama dengan yang diungkapkan Altieri dalam Nurndah (2015) bahwa konsep PHT dari suatu hubungan linier antara hama sasaran dan suatu strategi pengelolaan hama, menjadi suatu hubungan yang berupa jaringan (web) antara serangga hama, musuh alami dan keragaman tanaman (Nurindah, 2015). Konsep ini seperti ini mengedepankan pada pencarian faktor-faktor penyebab suatu agroekosistem menjadi rentan terhadap hama.

Salah satu pertanyaan yang juga tanyakan kepada para petani adalah pengetahuan mereka mengenai pupuk cair. Sayangnya, beberapa petani memiliki pengetahuan yang kurang mengenai pentingnya pupuk organik cair dalam pertanian. Selain itu, mereka juga masih mengalami beberapa kendala di lapangan terkait dengan masalah pertumbuhan dan produksi tanaman. Menurut respons yang didapatkan dari petani, mereka mampu mengenali gejala-gejala penyakit pada tanaman mereka. Meskipun mereka belum mampu untuk menangani hal tersebut dengan efisien dan efektif. Hal ini dapat menjadikan pembuatan pupuk organik cair dengan proses pengomposan yang menggunakan bahan baku limbah sayuran dapat dijadikan sebagai suatu usaha baru bagi para petani. Dengan demikian mereka dapat meningkatkan hasil-hasil produksi pertanian dan pendapatan mereka. Selain itu, dapat disimpulkan keluaran yang dicapai adalah sebagai berikut:

1. Pemanfaatan bahan lokal dalam pembuatan pupuk

2. Produk pupuk berbasis lokal

3. Peningkatan pendapatan masyarakat karena produksi pupuk.

4. Peserta Pelatihan mampu menggunakan bahasa inggris

5. Promosi produk menggunakan bahasa inggris. 
6. Manajemen yang baik dan pemasaran yang lebih luas.

Berdasarkan pada permasalahan dan tujuan kegiatan, maka kegiatan pengabdian ini telah menghasilkan 2 hal, yaitu:

a. Telah diadakan pelatihan kepada para petani untuk membuat pupuk organik ramah lingkungan dari sumber daya hayati yang banyak terdapat di lingkungan sekitar. Pelatihan dilaksanakan selama beberapa yang dihadiri oleh 25 peserta yang tergabung dalam kelompok tani masyarakat

b. Kegiatan pelatihan telah cukup efektif, yaitu bahwa $89 \%$ peserta pelatihan berniat untuk membuat sendiri pupuk organik dan $94 \%$ peserta akan mengaplikasikan pupuk organik di lahan pertanian mereka. Dari hasil evaluasi di lapangan, 3 minggu setelah pelatihan, lebih dari 50\% peserta telah menguji coba di lahan pertanian masing-masing.

Partisipasi mitra dalam pelaksanaan program PKM ini adalah mengikuti pelatihan dan pendampingan, serta mengajak para pelaku industri saraba dan warga masyarakat di sekitar lokasi Mitra untuk mengikuti kegiatan pelatihan dan pendampingan tentang peningkatan pengolahan limbah menjadi pupuk kompos ini. Dengan demikian, kegiatan PKM ini tidak hanya bermanfaat bagi mitra saja, tetapi juga semua pelaku usaha minuman tradisional serta warga masyarakat di sekitar lokasi yang membutuhkan.

\section{SIMPULAN}

Dari hasil kegiatan dan berdasar pada tujuan kegiatan, maka dapat disimpulkan bahwa kegiatan pengabdian masyarakat yang telah diadakan dapat disimpulkan bahwa mitra elah memberikan bekal pengetahuan dan keterampilan kepada para petani untuk membuat pupuk organik ramah lingkungan dari sumber daya hayati yang banyak terdapat di lingkungan sekitarnya. Terlebih lagi, pelaksanaan kegiatan telah berjalan secara efektif dengan melihat hasil evaluasi yang sesuai dengan target pencapaian.

\section{DAFTAR PUSTAKA}

Irianto, I. and Amrul, R. (2017) 'IbM Kelompok Pupuk Kompos Pemuda Mandiri Di Desa Bengkel Kecamatan Labuapi Kabupaten Lombok Barat', Valid Jurnal Ilmiah, 14(1), pp. 1-8. Available at: http://journal.stieamm.ac.id/index.php/valid/article/view/26.

Nurindah (2015) 'Pengelolaan Agroekosistem dalam Pengendalian Hama', Perspektif, 5(2), pp. 78-85. doi: 10.21082/p.v5n2.2006.

Praniti, N., Parining, N. and Putra, I. G. S. A. (2016) 'Strategi Pemasaran Untuk Meningkatkan Penjualan Pupuk Organik (Studi Kasus Pada Simantri 174 Gapoktan Dharma Pertiwi Kelurahan Lukluk, Kecamatan Mengwi, Kabupaten Badung)', E-Journal Agribisnis dan Agrowisata (Journal of Agribusiness and Agritourism), 5(1).

Tamrin, A. F. (no date) 'Children 's Literature: As a Way of Raising Environmental 
KANGMAS: Karya Ilmiah Pengabdian Masyarakat, Vol. 2 No. 1, March 2021 - 56

http://journal.neolectura.com/index.php/kangmas

Vol. 2, No. 1,

March, 2021,

pp. 50-56

e-ISSN:

2722-2004
Consciousness - A Study'.

Tamrin, A. F. and Magfirah, S. (2019) 'Nature Theme Pictured Book Used in Teaching English for Elementary Students', Eralingua: Jurnal Pendidikan Bahasa Asing dan Sastra, 3(1), pp. 16-25. doi: 10.26858/eralingua.v3i1.8759.

Wijayanto, H. et al. (2019) 'Pemberdayaan Kelompok Tani Desa Jatimalang, Kabupaten Pacitan melalui Pelatihan Pembuatan Pupuk Organik', Agrokreatif: Jurnal Ilmiah Pengabdian kepada Masyarakat, 5(2), pp. 109-114. doi: 10.29244/agrokreatif.5.2.109-114.
Training on

Making

Organic

Fertilizer and

Marketing for

Residents

in Pitiriawa

District,

Sidrap

Regency

F. Jumawan,

W. Darmawan,

A. F. Tamrin 